\title{
Primary School Class Teachers' Attitudes towards Teaching Contents of Cultural Heritage
}

\author{
Polona Jančič Hegediš, Vlasta Hus \\ Faculty of Education, University of Maribor, Maribor, Slovenia \\ Email: Polona.jancic1@um.si, Vlasta.hus@um.si
}

How to cite this paper: Hegediš, P. J., \& Hus, V. (2021). Primary School Class Teachers' Attitudes towards Teaching Contents of Cultural Heritage. Creative Education, 12, 2781-2791.

https://doi.org/10.4236/ce.2021.1212205

Received: November 3, 2021

Accepted: December 4, 2021

Published: December 7, 2021

Copyright $\odot 2021$ by author(s) and Scientific Research Publishing Inc. This work is licensed under the Creative Commons Attribution International License (CC BY 4.0).

http://creativecommons.org/licenses/by/4.0/ (c) (i) Open Access

\begin{abstract}
Teacher plays an important role in shaping and internalizing students' cultural values and consequently promotes conservation of cultural heritage, especially through teaching specific areas of social sciences. The article presents the empirical research that was conducted among 395 Slovenian primary school class teachers. The purpose of the research was to evaluate teachers' attitudes towards teaching cultural heritage. The results indicate that the surveyed teachers believe it is necessary to promote students' awareness of cultural heritage, since this encourages students to care for and protect cultural heritage. In addition, the surveyed teachers believe that students' care for and protection of cultural heritage would increase, if they could create their own mini museum or exhibit historic objects at school. The results also indicate that throughout the school year and when dealing with the contents of cultural heritage, teachers most often focus on knowledge, such as learning about old objects, monuments, values, beliefs, experience and feeling.
\end{abstract}

\section{Keywords}

Teaching, Cultural Heritage, Teachers, Primary School, Cultural Capital

\section{Introduction}

Education has evolved immensely with the world's global development. In the age of industrialization and the rise of capitalism, tangible and measurable results were of great importance as they tried to measure knowledge. As stated by Rutar Ilc (2004: p. 14), "this was the result of behaviourist conception of knowledge as unambiguous and explicable". Knowledge could be transferred independently from context and could also be objectively measured. The school and other educational institutions thus represented a place where the role of teachers as transmitters of knowledge and students as passive recipients was formed. In 
the second half of the last century, when science and technology flourished, it was clear that education should undergo thorough transformation, as the school, moulded in accordance with the old behavioural, cultural, and production patterns, became outdated and thus inefficient. "The changes encompass both, the notions of knowledge, as well as teaching and learning (Rutar Ilc, 2004: p. 14)." Quality knowledge of social sciences promotes understanding, tolerance and solidarity among people, nations, and racial and religious groups. Židan (2015: p. 24) claims that "knowledge of social sciences is a constant accompanying factor of man's unique identity" and that social sciences teachers can enrich students' personalities and enhance their values through the use of various didactic practices.

\section{Student Values and Cultural Capital}

Values are "constant accompanying factors of the work and pedagogical relationship between both actors of the pedagogical process, namely, between the teacher and the student (Židan, 2015: p. 28)" and are crucial for sustainable future. Values are "invariably of great importance for both, the individual as well as the society. A person cannot really exist without constantly evaluating what is either good or bad for him or her (Židan, 1996: p .21).” As a socializing institution, the school plays an important role in creating the world of values (Židan, 2004).

New kind of modern values and ethical and moral standards have emerged in today's globalized world and they have a noticeable influence on all generations. Among other, Židan lists the following contemporary social values: cosmopoli$\tan$ democracy, rule of law, values of coexistence, and personal freedom of the individual. Židan also points out that "just as we are obliged to protect important natural values, we should also contribute to the formation of new and better humanistic social values of global society (Židan, 2015: p. 29)." Namely, the individual's value system is formed in a complex and co-dependent globalized social context. Židan (2004) claims that school plays an important role in shaping and internalizing students' cultural values, especially through teaching specific areas of social sciences. Thus, school has a significant role in shaping and personalizing the values of an individual.

Bourdieu (1986), Colemann (2000), Putnam (2001) and others have attempted to define and place the concept of cultural capital. Bourdieu (2004) defines cultural capital as all material and/or symbolic goods that are presented as rare and we strive for them in a certain social formation. He distinguishes between symbolic, economic, social and cultural capital, all of which define an individual. According to Bourdieu (2004) three types of cultural capital should be distinguished and each type carries its own transmission logic, influencing the accumulation of the capital itself. Fulcher and Scott (2011) follow Bourdieu's cultural capital definition, highlighting the correlation between an individual's social class, culture, and education. Cultural capital can thus be understood as a com- 
plex and extensive concept; as a form of capital that refers to individuals' cultural and social activities and experiences related to their cultural activity. Consequently, the concept also includes the cultural heritage contents, which are the focus of the present article.

\section{Discussion of the Cultural Heritage Contents in the First Two Cycles of Primary Education}

After reviewing the curricula of primary education in Slovenia, we find that teachers can teach the contents of cultural heritage in most subjects of the compulsory program, as these contents are integrated in the syllabi of nearly all subjects.

It depends on each teacher individually which teaching methods or didactic strategies they will use when teaching the contents of cultural heritage. Selecting forms, methods, strategies and manners of teaching also depends on both, the goals teachers aim to achieve as well as the students' comprehension and skills. Marentič Požarnik (2008) suggests teachers should combine the methods they will use in class in accordance with the objectives of the subject, circumstances and students.

The research presented in this article focuses on class teachers' attitudes towards teaching cultural heritage in the first two three-year cycles of primary school. After obtaining the formally required education for teaching first and/or second cycle of primary school and after passing the professional examination, teachers' professional education and occupational training should both, respond to, as well as reflect the teachers' needs in their practice and should be constantly upgraded and updated. Discovering teachers' attitudes is important to efficiently plan and offer teachers additional professional training programs. Not only to acquaint teachers with modern teaching approaches, but also to train them to develop children's values and build their social and cultural capital. As Kramar (2004) saying that teacher's knowledge and practices should be upgraded and improved continuously and in accordance with the development of teaching guidelines. According to Šteblaj (2004), further teacher education includes the following elements: teacher education at the school where the teacher is employed, carried out by managers, coordinators or external co-workers; seminar and workshop education; improvement of weaker skills and knowledge; and the use of professional literature and material. Teacher training programs also include various forms of research, problem-based and collaborative learning, and experiential learning.

The Slovenian National Education Institute established the continuous professional training programme, the aim of which is to refresh and upgrade the teachers' knowledge of individual didactic concepts and models (Nolimal, 2004). Important teacher education advancements are also taking place in higher education, where increasing importance is given to the implementation of studentcentred learning. The idea of active learning and teaching has been the subject of study in our country since the middle of the last century, however, as Cvetek 
(2019) claims, it has still not properly been applied in practice. Evaluating the quality of higher teaching education and education processes have recently become increasingly associated with the didactic training of teachers and their professional development (Cvetek, 2019).

\section{Methodology}

\subsection{Purpose of the Study}

The aim of our research was to evaluate the primary school class teachers' attitudes towards teaching cultural heritage. The class teacher's role in the educational process is extensive and complex, as it includes all dimensions of the educational process. Teachers and the entire school system can influence the construction of student values, their social and cultural capital.

\subsection{Research Method}

As a basic research method, we used descriptive and non-experimental method of pedagogical research.

\subsection{Research Sample}

Our research sample includes 395 class teachers, who were teaching the first two cycles of primary school in 2018.

\subsection{Instrument}

We collected the data with a questionnaire, which, among other, included the following 6 statements:

1) Students' awareness of cultural heritage should be encouraged.

2) Cultural heritage themes included in the environmental studies and social studies classes stimulate students to care for and preserve cultural heritage.

3) Cultural heritage themes included in the environmental studies and social studies classes are adequate.

4) Cultural heritage themes included in the environmental studies and social studies classes are sufficient.

5) Teaching cultural heritage contents outside the classroom most efficiently encourages students to care for and protect cultural heritage.

6) Students' care for and protection of cultural heritage would increase, if they made their own mini museum or exhibit historic objects at school.

Teachers rated the above-mentioned statements with the help of a scale from 1 , meaning that they completely disagree, to 5 , meaning that they completely agree. Consequently, we were also interested in finding how often it occurs that teachers consider the below mentioned elements while teaching the contents of cultural heritage.

Our article focuses on the results of the questionnaire that deal with the attitudes of those teachers, who teach contents of cultural heritage in the first two cycles of primary school. 
We ensured validity with reviewing and pre-testing our questionnaire on a sample. Reliability was controlled from the start of creating questions since we were careful to provide detailed instructions and unambiguous specific questions. Reliability was also monitored when processing data since we compared the answers to content-related questions. When examining the attitudes towards individual statements, we used the Cronbach's alpha coefficient ( $\alpha$ ). As results show, the alpha coefficient amounts to 0.709 , which means good reliability. Should the reliability be poor, this would mean that the influence of coincidences or testing circumstances on the results is great, thus, we cannot be sure that the questionnaire would show the same results next time. The objectivity of instrument was based on individual interviewing without the presence of an assessor.

\subsection{Data Collection and Analysis}

We collected the data with a survey questionnaire intended for primary school class teachers. We obtained the web addresses of primary schools on the Ministry of Education, Science and Sport website and sent the schools an e-mail including the link to an online survey, carried out at https://www.1ka.si/. Once we completed the survey, there were 395 fully completed questionnaires in our database.

The data obtained from the questionnaires were analysed by using the SPSS statistics programme. For data processing, we used basic descriptive statistics and frequency distribution. For examining the differences in teachers' attitudes in accordance with their period of employment and the grade they are teaching, we used the Kruskal-Wallis test for independent samples; and for examining the differences in teachers' attitudes towards the teaching environment, we used the Mann-Whitney test.

During the analysis, we also checked for statistically relevant differences between participants regarding their age, teaching environment and teachers' period of employment. The difference between the groups was considered statistically significant, if the degree of risk for the validity of the null hypothesis was less than five per cent. The level at which the null hypothesis is rejected is usually set at five or fewer times out of 100 . The 0.05 probability level is acceptable as a reasonable choice in most social studies research (Cramer \& Howitt, 2004, Field, 2013).

\section{Results}

\subsection{Primary School Class Teacher's Attitudes towards Teaching Contents of Cultural Heritage}

In Table 1, we present numbers, structural percentages and the average level of agreement with an individual statement.

The results show that teachers ranked the statement that it is necessary to promote students' awareness of cultural heritage as highly important, the value of the average level amounting to 4.74 .310 teachers, that is $78.5 \%$ of all surveyed 
Table 1. Numbers (f), structural percentages (f\%) and the average level of agreement with an individual statement (R).

\begin{tabular}{|c|c|c|c|c|c|c|c|}
\hline \multirow[b]{2}{*}{ Statement } & \multicolumn{7}{|c|}{ Level of agreement } \\
\hline & $\begin{array}{l}\text { Completely } \\
\text { disagree } \\
\mathrm{f} \\
\mathrm{f} \%\end{array}$ & $\begin{array}{l}\text { Disagree } \\
\qquad \mathrm{f} \\
\mathrm{f} \%\end{array}$ & $\begin{array}{l}\text { Partially } \\
\text { agree } \\
\text { f } \\
\text { f\% }\end{array}$ & $\begin{array}{l}\text { agree } \\
\mathrm{f} \\
\mathrm{f} \%\end{array}$ & $\begin{array}{l}\text { Completely } \\
\text { agree } \\
\text { f } \\
\text { f\% }\end{array}$ & $\begin{array}{l}\text { Total } \\
\mathrm{f} \\
\mathrm{f} \%\end{array}$ & $\bar{R}$ \\
\hline $\begin{array}{l}\text { Students' awareness of cultural heritage } \\
\text { should be encouraged. }\end{array}$ & $\begin{array}{c}3 \\
0.8 \%\end{array}$ & $\begin{array}{c}0 \\
0.0 \%\end{array}$ & $\begin{array}{c}8 \\
2.0 \%\end{array}$ & $\begin{array}{c}74 \\
18.7 \%\end{array}$ & $\begin{array}{c}310 \\
78.5 \%\end{array}$ & $\begin{array}{c}395 \\
100 \%\end{array}$ & 4.74 \\
\hline $\begin{array}{l}\text { Cultural heritage themes included in } \\
\text { the environmental studies and social } \\
\text { studies classes stimulate students to } \\
\text { care for and preserve cultural heritage. }\end{array}$ & $\begin{array}{c}2 \\
0.5 \%\end{array}$ & $\begin{array}{c}3 \\
0.8 \%\end{array}$ & $\begin{array}{c}34 \\
8.6 \%\end{array}$ & $\begin{array}{c}136 \\
34.4 \%\end{array}$ & $\begin{array}{c}220 \\
55.7 \%\end{array}$ & $\begin{array}{c}395 \\
100 \%\end{array}$ & 4.44 \\
\hline $\begin{array}{l}\text { Cultural heritage themes included in } \\
\text { the environmental studies and social } \\
\text { studies classes are adequate. }\end{array}$ & $\begin{array}{c}1 \\
0.3 \%\end{array}$ & $\begin{array}{c}10 \\
2.5 \%\end{array}$ & $\begin{array}{c}69 \\
17.5 \%\end{array}$ & $\begin{array}{c}179 \\
45.3 \%\end{array}$ & $\begin{array}{c}136 \\
34.4 \%\end{array}$ & $\begin{array}{c}395 \\
100 \%\end{array}$ & 4.11 \\
\hline $\begin{array}{l}\text { Cultural heritage themes included in } \\
\text { the environmental studies and social } \\
\text { studies classes are sufficient. }\end{array}$ & $\begin{array}{c}3 \\
0.8 \%\end{array}$ & $\begin{array}{c}26 \\
6.6 \%\end{array}$ & $\begin{array}{c}121 \\
30.6 \%\end{array}$ & $\begin{array}{c}144 \\
36.5 \%\end{array}$ & $\begin{array}{c}101 \\
25.6 \%\end{array}$ & $\begin{array}{c}395 \\
100 \%\end{array}$ & 3.79 \\
\hline $\begin{array}{l}\text { Teaching cultural heritage contents } \\
\text { outside the classroom most efficiently } \\
\text { encourages students to care for and } \\
\text { protect cultural heritage. }\end{array}$ & $\begin{array}{c}1 \\
0.3 \%\end{array}$ & $\begin{array}{c}6 \\
1.5 \%\end{array}$ & $\begin{array}{c}37 \\
9.4 \%\end{array}$ & $\begin{array}{c}135 \\
34.2 \%\end{array}$ & $\begin{array}{c}216 \\
54.7 \%\end{array}$ & $\begin{array}{c}395 \\
100 \%\end{array}$ & 4.42 \\
\hline $\begin{array}{l}\text { Students' care for and protection of } \\
\text { cultural heritage would increase if they } \\
\text { made their own mini museum or } \\
\text { exhibit historic objects at school. }\end{array}$ & $\begin{array}{c}2 \\
0.5 \%\end{array}$ & $\begin{array}{c}5 \\
1.3 \%\end{array}$ & $\begin{array}{c}51 \\
12.9 \%\end{array}$ & $\begin{array}{c}124 \\
31.4 \%\end{array}$ & $\begin{array}{c}213 \\
53.9 \%\end{array}$ & $\begin{array}{c}395 \\
100 \%\end{array}$ & 4.37 \\
\hline
\end{tabular}

participants, completely agree with the statement. The average level of agreement of teachers believing that students' care for and protection of cultural heritage increases, while teaching such themes in environmental sciences, amounts to 4.44. Surveyed teachers also agreed and completely agreed with the statement that teaching contents of cultural heritage outside the classroom encourages students to protect cultural heritage, the value of agreement amounting to 4.42. Teachers also strongly agreed with the statement that students would care for and protect cultural heritage more, if they made their own mini museum or historic object exhibition at school, the level of agreement amounting to $4.37 .45 .3 \%$ of teachers agree and $34.4 \%$ completely agree with the statement that cultural heritage themes taught in environmental and social studies subjects are adequate. $36.5 \%$ of teachers agree, $30.6 \%$ partly agree and $25.6 \%$ completely agree with the statement that the quantity of cultural heritage themes being taught is adequate.

We used the Kruskall-Wallis and Mann-Whitney tests to identify the differences between groups of teachers in terms of period of employment, what grade they are teaching, and their teaching environment. The results show that there 
are statistically significant differences among teachers according to their period of employment for the first three statements. Teachers with longer periods of employment agreed more with the statement that it is necessary to promote students' awareness of cultural heritage than their younger colleagues with shorter periods of employment. Additionally, teachers with longer periods of employment agreed significantly more than their younger colleagues with shorter periods of employment with the statements that students' care for and protection of cultural heritage increases while teaching such themes in environmental and social studies; and that the cultural heritage themes taught in environmental studies subject are adequate.

Furthermore, the results show that there are no statistically significant differences among teachers in relation to the grade they teach. Results indicate that there are no statistically significant differences among teachers in regard to teaching environment for the first four statements. Mann-Whitney test results of the last two statements indicate that there are statistically significant differences among teachers teaching in urban and rural schools. In both statements, teachers who teach in rural schools agree more with the statement than their counterparts who teach in urban schools. Thus, rural teachers agree more with the statements that teaching cultural heritage contents outside the classroom most efficiently encourages students to care for and protect cultural heritage and that students' care for and protection of cultural heritage would increase, if they made their own mini museum or exhibit historic objects at school.

\subsection{How Often Do Teachers Consider the Elements Listed Below While Teaching Cultural Heritage?}

It was our aim to find how frequently teachers include knowledge, skills, values, beliefs, experiencing and feeling, all of which represent individual elements of cultural heritage. The results are shown in Table 2.

The results in Table 2 indicate that the most frequently included element in teaching cultural heritage throughout the school year is knowledge, that is, learning about historic objects, monuments and the like $(\bar{x}=2.68)$. Values and beliefs $(\bar{x}=2.54)$ and experiencing and feeling $(\bar{x}=2.54)$ are also often considered. Teachers least frequently include skills such as making baskets or lace $\left(\begin{array}{l}\bar{X} \\ =2.00\end{array}\right)$ and any other cultural heritage elements.

In this regard, we were also interested in finding whether there are differences among teachers in relation to their period of employment, the grade they teach and their teaching environment. For each of the individual contents, we performed the $\chi^{2}$-test of the frequency of considering individual cultural heritage components while teaching, according to period of employment, the grade the teachers are teaching and their teaching environment. We present only the $\chi^{2}$-test results, which indicate statistically significant differences. There are no statistically significant differences in the frequency of considering cultural heritage knowledge among the surveyed teachers according to their period of employment, the grade they are teaching and their teaching environment. In regard to the 
Table 2. Number (f), structural percentages (f\%) and average value $(\bar{x})$ of the frequency of including individual elements of cultural heritage in a school year

\begin{tabular}{cccccc}
\hline & \multicolumn{5}{c}{ Frequency of including individual elements of } \\
& \multicolumn{5}{c}{ cultural heritage in a school year } \\
\cline { 2 - 6 } Answers & Never & Rarely & Often & Total & \\
& $\mathrm{f}$ & $\mathrm{f}$ & $\mathrm{f}$ & $\mathrm{f}$ & $\bar{x}$ \\
& $\mathrm{f} \%$ & $\mathrm{f} \%$ & $\mathrm{f} \%$ & $\mathrm{f} \%$ & \\
Knowledge & 4 & 120 & 271 & 395 & 2.68 \\
& $1.0 \%$ & $30.4 \%$ & $68.6 \%$ & $100.0 \%$ & \\
Skills & 66 & 263 & 66 & 395 & 2.00 \\
& $16.7 \%$ & $66.6 \%$ & $16.7 \%$ & $100.0 \%$ & \\
Values, beliefs & 18 & 146 & 231 & 395 & 2.54 \\
& $4.6 \%$ & $37.0 \%$ & $58.5 \%$ & $100.0 \%$ & \\
Experiencing and feeling & 18 & 145 & 232 & 395 & 2.54 \\
& $4.6 \%$ & $36.7 \%$ & $58.7 \%$ & $100.0 \%$ & \\
& 24 & 14 & 6 & 44 & 1.59 \\
Other & $54.6 \%$ & $31.8 \%$ & $13.6 \%$ & $100.0 \%$ & \\
\hline
\end{tabular}

frequency of including skill development, there are also no differences among teachers according to their period of employment and the grade they are teaching.

Statistically significant differences $\left(\chi^{2}=7.475, P=0.024\right)$ are evident among teachers according to their teaching environment. Namely, teachers who teach in rural areas tend to focus on skill development more than their counterparts who teach in urban primary schools. In terms of the frequency of including values and beliefs in the context of cultural heritage, the results show statistical differences according to the grade they teach $\left(\chi^{2}=34.067, P=0.000\right)$. Teachers teaching higher grades are more likely to focus on values and beliefs than teachers of lower grades. There are no statistically significant differences in the frequency of including experience and feeling among teachers in accordance with the period of employment, the grade teachers teach and their teaching environment.

\section{Discussion and Conclusion}

The empirical research presented in this article is part of a broader research on cultural heritage taught in the first two cycles of primary school. However, the results presented and analyzed in this article show that the surveyed teachers believe it is necessary to promote students' awareness of cultural heritage. One of the objectives of Slovenian primary education is to develop the awareness of national origin and national identity, Slovenian history, Slovenian cultural and natural heritage. The objectives also include the promotion of civic responsibility (ZOsn, 2016). Teachers also believe that students' care for and protection of cultural heritage increases while learning about related topics in environmental and so- 
cial studies. The surveyed teachers agreed with the statement that teaching the content of cultural heritage outside the classroom most encourages students to protect it.

In addition, the surveyed teachers believe that students' care for and protection of cultural heritage would increase, if they made their own mini museum or exhibit historic objects at school, which actively involves the students in the educational process. Active learning enables students to acquire knowledge through their own experiences and activities, which positively affects their motivation to learn (Mithans, 2017; Mithans and Ivanuš Grmek, 2019). The type of learning that combines and connects a person's sensory and emotional experience, thinking, analysing and being active is defined in the theoretical part of this article as experiential learning.

Based on the results of our research, we can conclude that while teaching the contents of cultural heritage throughout the school year, teachers most frequently focus on knowledge, such as learning about historical objects and monuments; values and beliefs; and experience and feeling. Teachers teaching higher grades are more likely to focus on values and beliefs than teachers teaching lower grades. Teachers least frequently focus on skills such as making baskets or lace and

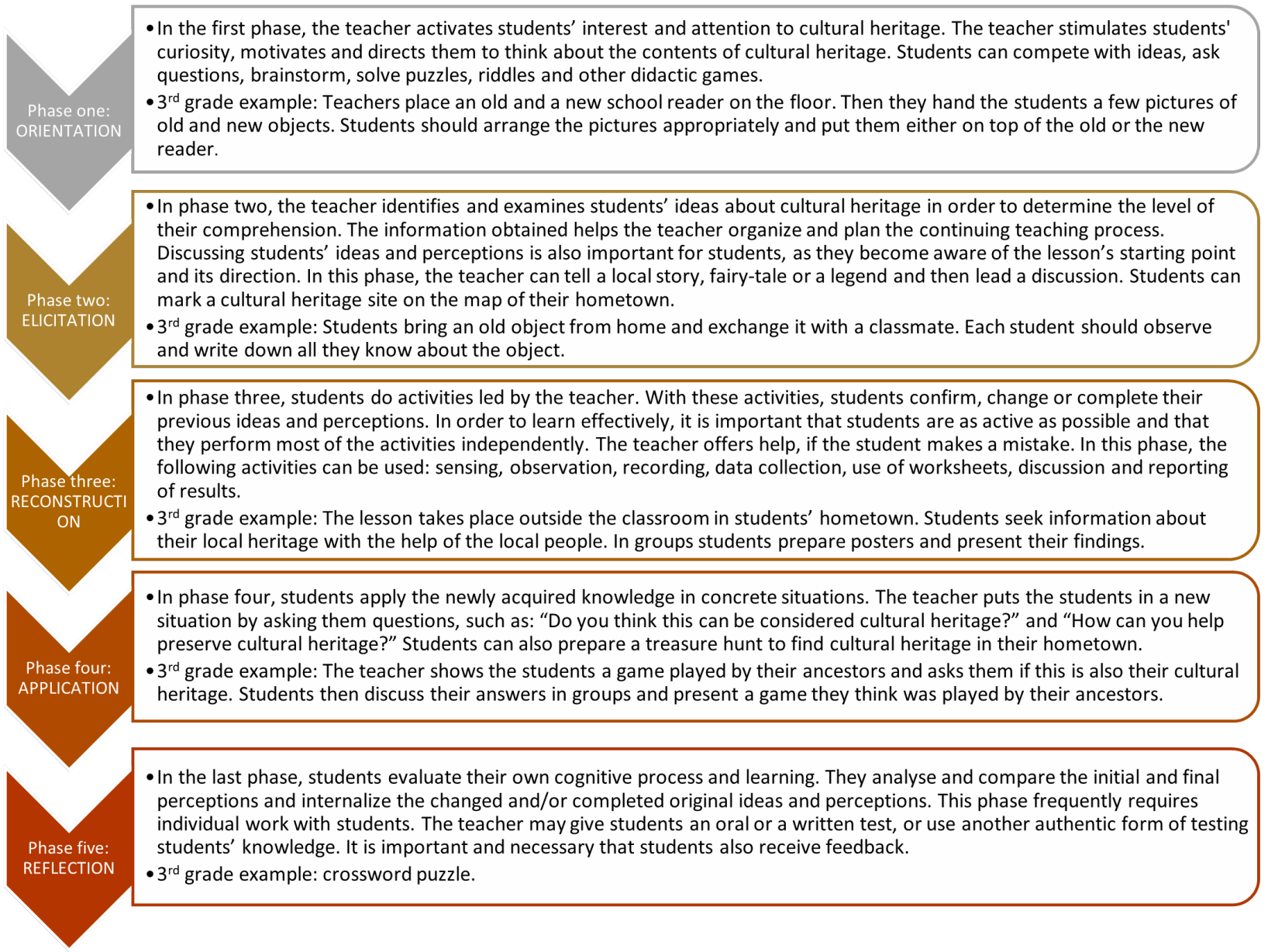

Figure 1. The model of teaching cultural heritage. 
similar creativity. Rural teachers tend to focus on skill development more than their counterparts who teach in urban primary schools.

Based on our findings, we believe that in the early stages of education, teachers should increasingly encourage students' individualized intrinsic motivation sources and develop their positive and responsible attitudes towards cultural heritage.

Finally, we present a cultural heritage teaching model we designed in accordance with the constructivist theory of learning and teaching. We prepared our example according to the phases listed by Hus (2011) in her constructivist lesson, entitled Influence of Weather. The phases were also described by Krapše (1999) and Ferbar (1993), who led the Tempus Project in Slovenia, titled Development of Initial Science.

The model of teaching cultural heritage: (Figure 1).

We would like to add the following notes to the model presented above:

- When teaching cultural heritage, teachers should adapt our model to students' age and other student specifics.

- There is no time frame determined for the above-mentioned phases. They can be combined; however, omitting individual phases should be avoided.

- The environment in which lessons are held should be complex and challenging.

- The activities that teachers select should encourage students to be as active as possible in completing the tasks given by their teacher.

\section{Conflicts of Interest}

The authors declare no conflicts of interest regarding the publication of this paper.

\section{References}

Bourdieu, P. (1986). The Forms of Capital. In J. Richardson (Ed.), Handbook of Theory and Research for the Sociology of Education (pp. 15-29). Greenwood.

Bourdieu, P. (2004). Oblike kapitala. In F. Adam, \& M. Tomšič (Ed.), Kompendij socioloških teorij (pp. 311-324). Študentska založba.

Coleman, J. S. (2000). Social Capital in the Creation of Human Capital. In E. L. Lesser (Ed.), Knowledge and Social Capital. Foundations and Applications (pp. 17-41). Butterworth-Heinemann. https://doi.org/10.1016/B978-0-7506-7222-1.50005-2

Cramer, D., \& Howitt, D. L. (2004). The SAGE Dictionary of Statistics: A practical Resource for Students in Social Sciences. SAGE Publications Ltd.

https://doi.org/10.4135/9780857020123

Cvetek, S. (2019). Na študenta osredinjeno poučevanje. Priročnik za visokošolske učitelje. Akadem.

Ferbar, J. (1993). Tempusovo snopje: Tempusova projektna skupina. DZS.

Field, A. (2013). Discovering Statistics Using IBM SPSS Statistics (4th ed.). SAGE Publications Ltd.

Fulcher, S., \& Scott, J. (2011). Sociology (4th ed.). Oxford University Press. 
Hus, V. (2011). "Vpliv vremena" na razvoj kompetenc učencev v tretjem razredu osnovne šole. In V. Grubelnik (Ed.), Razvoj naravoslovnih kompetenc-Izbrana gradiva projekta: strokovna monografija (pp. 10-13). Fakulteta za naravoslovje in matematiko.

Kramar, M. (2004). Konstruktivizem in učiteljeva vloga v izobraževalnem procesu. In B. Marentič Požarnik (ed.), Konstruktivizem v šoli in izobraževanje učiteljev (pp. 113-122). Center za pedagoško izobraževanje filozofske fakultete.

Krapše, T. (1999). Konstruktivizem kot didaktični model. Simpozij. Modeli poučevanja in učenja (str. 66-70). Zavod RS za šolstvo.

Marentič Požarnik, B. (2008). Konstruktivizem na poti od teorije spoznavanja do vplivanja na pedagoško razmišljanje, raziskovanje in učno prakso. Sodobna pedagogika, 59, 28-51.

Mithans, M. (2017). Participacija učencev pri pouku in na šoli [Doctoral Dissertation]. Univerza v Mariboru, Pedagoška fakulteta. https://dk.um.si/Dokument.php?id=119373

Mithans, M., Ivanuš Grmek, M. (2019). Open Classes and Participation in DecisionMaking in Class. Hrvatski časopis za odgoj i obrazovanje = Croatian Journal of Education, 21, 167-180.

Nolimal, F. (2004). Kakovostne didaktične odločitve-Posledice izkušenjskega dela učiteljev. In B. Marentič Požarnik (Ed.), Konstruktivizem $v$ šoli in izobraževanje učiteljev (pp. 629-656). Center za pedagoško izobraževanje filozofske fakultete. https://doi.org/10.15516/cje.v21i0.3432

Putnam, R. D. (2001). Bowling Alone: The Collapse and Revival of American Community. Simon \& Schluster. Association for Computing Machinery. https://doi.org/10.1145/358916.361990

Rutar Ilc, Z. (2004). Pristopi k poučevanju, preverjanju in ocenjevanju. Zavod Republike Slovenije za šolstvo.

Šteblaj, L. (2004). Procesno spremljanje učiteljevega razvoja in izobraževanja. In B. Marentič Požarnik (Ed.), Konstruktivizem v šoli in izobraževanje učiteljev (pp. 613627). Center za pedagoško izobraževanje filozofske fakultete.

Zakon o osnovni šoli (ZOsn) (2016). http://www.mizs.gov.si/si/delovna podrocja/direktorat za predsolsko vzgojo in osn ovno solstvo/osnovno solstvo/

Židan, A. (1996). Metadidaktično poučevanje in učenje družboslovja. Fakulteta za družbene vede.

Židan, A. (2004). Za kakovostnejša družboslovna znanja. Didaktični in znanstveni prispevki. Fakulteta za družbene vede.

Židan, A. (2015). Temeljne značilnosti postmoderne didaktike družboslovja. Fakulteta za družbene vede. 